\title{
Increasing Parental Involvement In Our Schools: The Need To Overcome Obstacles, Promote Critical Behaviors, And Provide Teacher Training
}

Gregory V. Flynn, (Email: flynng@dowling.edu), Dowling College

\begin{abstract}
This paper examines critical parental behaviors for student success as well as the major obstacles for parental involvement. Suggestions are given for improving preservice training in teacher education programs.
\end{abstract}

\section{INTRODUCTION}

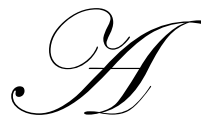

n ever growing body of research indicates that parental involvement is a key factor in the success of children in school (Aronson, 1996; Ballantine, 1999; Brown, 1999; Chen \& Chandler, 2001; Columbo, 1995; Gonzalez, 2002; Huss-Keeler, 1997; Masten \& Coatsworth, 1998; Norton \& Nufeld, 2002; Vincent, 1996; Zellman \& Waterman, 1998). Studies have shown that children whose parents take an active interest in their education benefit in a number of ways. These children generally have higher academic achievement (Becher, 1984; Henderson, Marburger, \& Ooms, 1986), better attendance (Haynes, Comer, \& Hamilton-Lee, 1989), a sense of well-being (Cochran, 1987), a readiness to do homework (Rich, 1988), and better self-regulatory skills (HooverDempsey, Walker, Jones, \& Reed, 2002). These positive effects are not confined to elementary school but continue through high school (Henderson, 1987; Hickman, Greenwood, \& Miller, 1995).

Less publicized, but still important, are the ways in which teachers profit from developing alliances with parents. Teachers who promote partnerships with parents report reduced stress levels, experience empowerment to teach more effectively, and realize higher professional status and authority (Lazar \& Slostad, 1999). Parental involvement is attributed to a greater recognition of teachers' skills and better evaluations (Christensen \& Cleary, 1990). In addition, Hara and Burke (1998) reported that teachers gain greater respect for their work from parents as a result of parental involvement.

Realizing the importance of parental participation, and in an effort to raise the educational standards in this country, the federal government and national accreditation agencies have mandated that teachers be trained to work with parents and that schools develop partnerships with parents. For example, the No Child Left Behind Act of 2001 (P.L. 107-110), and the Goals 2000 Educate America Act require all schools to promote parent partnerships. The National Council for Accreditation of Teacher Education has developed standards that require preservice teachers to be trained to collaborate with parents (National Council for Accreditation of Teachers, 1994).

\section{THE LACK OF PARENTAL INVOLVEMENT}

It is reasonable to assume with such attention given to the importance of parental involvement both in the literature and by the government that there has been a significant increase in parent participation in our schools. As most classroom teachers know, this is not the case. In fact teachers report that the lack of involvement of parents is a major obstacle to school improvement (Langdon \& Vesper, 2000). Steinberg (1996) stated that parents, for the most part, are disengaged from their children's education. In a recent article, Long and Williams (2005), categorized 
parental involvement as often nonexistent. Whatever support children do receive from their parents at the elementary level that support rapidly declines as students enter middle school and high school (Epstein, 1984, 1995; HooverDempsey \& Sandler, 1997; U.S. Department of Education, 1998).

Parents are not solely to blame for the lack of home-school communication. Few teachers use strategies that encourage parental involvement (Tichenor, 1997), and many teachers believe that it is not their responsibility to contact parents (Schweiker-Mara, 2000). Although there are examples of school programs that successfully promote parental involvement, these programs are too few in number. In order to improve this situation, obstacles to communication faced by both parents and teachers must be overcome and behaviors identified as being most important for academic success must be promoted.

\section{THE PURPOSE OF THIS ARTICLE}

The purpose of this article is to examine the obstacles that must be overcome by both parents and teachers before meaningful parent-school partnerships can be established; to identify those parent and teacher behaviors that are most critical for children's academic success; and finally to discuss the need for teacher training in order to foster parent-teacher alliances.

\section{OBSTACLES FOR PARENTS}

Let's begin by discussing some of the reasons why many parents are reluctant to talk to teachers. For most teachers, school was a pleasant experience; it is one of the reasons why they entered the profession. For many parents, however, their own childhood experiences in school were negative. Some parents experienced failure, ridicule, and some dropped out before graduation (Greenwood \& Hickman, 1991; Katz, 1996). In addition, parents often complain that teachers do not make enough effort to understand their children, that they lack care and concern (Henderson, Marburger, \& Ooms, 1986). These negative feelings are projected onto their own children and both the parents and their children become defensive about school. Therefore it is important for teachers to convey to these parents, as well as to their children, that they care about their students as individuals and that they have a genuine concern for the children's welfare.

A second reason why parents hesitate talking to teachers is that usually the only time that teachers call parents is to report a problem (Henderson, Marburger, \& Ooms, 1986). Many parents are already overwhelmed by trying to raise a family while working a full-time job. The number of single-parent families has dramatically increased in recent years (U.S. Department of Education, 1996) and the last thing that these parents want to hear is more problems. There are two things that teachers can do to counteract this situation. First, efforts have to be made so that the first communication with a parent is a positive one. A welcoming letter or a phone call early in the year to simply say that the teacher is looking forward to a great year with their child can go a long way in developing a positive relationship. When it is necessary to contact parents because of a problem, teachers need to be prepared to offer simple strategies that parents can implement with the teacher's guidance in order to remedy the situation. Who would want to go to a doctor and hear about a problem without the doctor offering a solution?

Parents are often intimidated by school, sometimes because of the educational jargon that teachers use, sometimes by the nature of the curriculum, and sometimes because the teacher does not show the parents the proper respect. Communication with parents is most productive when parents are treated as equals, when good listening skills are employed, and when the teacher begins and ends the conversation on a positive note (Coleman, 1991). Parents need to know that it is not necessarily their responsibility to tutor their children in the subject matter but rather to establish an environment at home that encourages learning (Muller, 1993).

Unfortunately some parents try to divorce themselves from their parental responsibilities. These are the types of parents who will tell a teacher "he is your problem from 9 to 3" or "she is fourteen and is old enough to take responsibility for her own actions, don't call me." It's sad, but as any tenured teacher knows, it's too often true. Teachers cannot give up on children from these types of homes. They need to find reasons to communicate positive student behavior, offer parents strategies to correct the problem situations and to be persistent in informing parents of 
the progress that the child is making, even when the parents tell the teacher not to contact them. When warranted, other school personnel should be advised of the situation and a team approach should be used with these types of parents.

Diversity in our schools is continually growing and as a result language barriers are becoming more problematic (Huss-Keeler, 1997; Reed-Danahay, 1996). With families that do not speak English teachers need to send home notices written in the families' native language, have interpreters available during conferences, or use the parents' extended families to assist in communications between home and school (Inger, 1992).

Ironically many parents don't understand their own importance in their children's education (HooverDempsey, Walker, Jones, \& Reed, 2002) and therefore see no need to be involved with the school. Other parents feel that they lack the skills to help their children once they enter school (Ballantine, 1999; Greenwood \& Hickman, 1991; Morris, Taylor, Knight, \& Watson, 1995). For these parents teachers must continually emphasize the fact that parents are the single most important factor in their children's success in school. Parents can exert a tremendous influence on their children's education without understanding Algebra and without tutoring their children in Chemistry. All parents possess the capacity to engage in the essential behaviors that lead to academic success and it is the classroom teacher who can assist the parents in understanding those behaviors.

\section{OBSTACLES FOR TEACHERS}

Obstacles to parent-teacher communication do not fall solely on the shoulders of parents. Teachers too face a number of hurdles causing them to be reluctant to contact parents.

For generations many teachers have believed that parents do not value education, do not prepare their children adequately for school, and do little at home to motivate learning (Ascher, 1988). Teachers often complain that parents do not support their efforts, and do not discipline their children when misbehavior occurs (Henderson, Marburger, \& Ooms, 1986). Therefore these teachers believe it is pointless to contact the home.

No one likes a confrontation and teachers often see parents as being suspicious and hostile. They fear that the parents will be argumentative when they are contacted (Greenwood \& Hickman, 1991; Johnson \& Webster, 1994). Some teachers are misguided in their belief that if they avoid contacting the parents they will reduce confrontations. Ironically, just the opposite is true (Johnson \& Webster). Teachers who promptly contact parents when problems arise avoid the escalation of the problems and generally receive parental appreciation and support. Still other teachers believe that contacting parents is not their job but rather the responsibility of the administration and guidance (Schweiker-Mara, 2000).

Another reason for teachers failing to communicate with the family is teachers' lack of understanding of the importance of parental involvement (Broderick \& Mastrilli, 1997; Greenwood \& Hickman, 1991; Hoover-Dempsey, Walker, Jones, \& Reed, 2002) and their beliefs about parents' efficacy in improving academic success (HooverDempsey, Walker, Jones, \& Reed; Lazar \& Slostad, 1999). New teachers as well as tenured ones are ill-informed about the benefits of fostering alliances with parents that have been described in the literature for decades.

However, the most serious obstacle to increasing parental involvement in our schools is the failure of our teacher education programs to adequately train preservice teachers (Epstein, 1995; Greenwood \& Hickman, 1991; Hinz, Clarke, \& Nathan, 1992; Hoover-Dempsey, Walker, Jones, \& Reed, 2002; Tichenor, 1997). Only $4 \%$ of our nation's teachers report taking a course dealing with parental involvement as part of their preservice training (U.S. Department of Education, 1994). Fero and Bush (1994) stated that it is possible that there is no other teaching skill for which teachers are less prepared. Of course there have been some teacher educator programs developed to increase teacher commitment to family involvement but these programs reach a very small proportion of the population (de Acosta, 1996).

As a result of our failure to train teachers to effectively communicate with the home, teachers lack the skills and the belief that they can effectively involve parents (Morris, Taylor, Knight, \& Watson, 1995). This lack of a 
personal sense of efficacy presents a significant impediment in supporting a teacher's efforts to involve the family (Bandura, 1997; Hoover-Dempsey, Bassler, \& Brissie; 1992).

\section{ESSENTIAL PARENTAL BEHAVIORS}

Researchers have identified several types of parental involvement. Epstein (1995) categorized this involvement as parenting, communicating, volunteering, learning at home, decision making, and collaborating with the community. These categories are similar to the ones established by the National PTA (1997) and Henderson, Marburger, \& Ooms (1986). Although each of these parental behaviors have some type of positive impact on the home, school, and community, not all are equal in regard to increasing academic achievement. What appear to be most essential for student success are those relationships established between parents and children at home (Burns, 2000; Clark, 1983; Norton \& Nufeld, 2002). Let's discuss some of these behaviors.

First, parents need to have high expectations for their children and make education a priority in the family (Brown, 1999; Kurdek, Fine, \& Sinclair, 1995; Muller, 1993; Rosenzweig, 2000; Solo, 1997). The most successful students come from families that maintain high expectations for their children and where the importance of a good education is continuously emphasized (Clark, 1983). Similarly, one of the most important characteristics of successful teachers is setting high standards for students (Hughes, 2003; Johnson, 1998). Teachers need to be mindful of how important this is and to continuously emphasize to parents that their children are capable of achieving a great deal of academic success.

Second, parents cannot give just lip service to their children's education but instead they need to be actively involved in learning activities at home (Becker \& Epstein, 1982; Dornbusch \& Ritter, 1988; Tizard, Schofeld, \& Hewison, 1982; Rosenzweig, 2000). Children do best when their routines at home are well structured by their parents (Muller, 1993). Teachers can assist parents by offering specific strategies that parents can use to actively organize and monitor their children's time, help with homework, and discuss school matters (Finn, 1998). Parents can provide materials, set up study areas conducive to learning, help children understand directions, and, in general, show interest in their children's schoolwork. Frequent discussions about school not only help parents to monitor their children's activities, but perhaps more importantly, they show children that their parents care about their progress (Brown, 1999; Finn, 1998). Parents can more easily monitor school progress if teachers provide parents with needed information such as homework policies that discuss the type, frequency, and amount of homework generally given, grading policies, dates when reports will be sent out, a brief description of the content of the course, and special projects and activities that will occur during the year. In fact, parents generally welcome this type of information (Loucks, 1992). Most of this information can be presented in a welcoming letter during the first week of school, periodic newsletters sent home, phone calls, and emails. It is important for teachers to remember that it is difficult for parents to monitor their children without receiving this information.

Third, both parents and teachers need to emphasize effort over ability (Stevenson, 1983). Research has noted that children who attribute success and failure to effort rather than ability gain satisfaction through the exertion of effort, seek challenges, and are persistent in the face of obstacles (Dweck, 1986). In addition, self-efficacy is increased when the learner believes that outcomes are related to effort (Fowler \& Peterson, 1981). Neither parents nor teachers can significantly change the ability of students but they can have an important impact on altering students' attributional styles. Students are most successful when both parents and teachers convey to them that they can succeed with sufficient effort.

Over the past decades researchers have identified a type of parenting termed "authoritative" that appears to be most conducive to academic success (Darling \& Steinberg, 1993; Gonzalez, 2002; Robertson, 1997; Rosenzweig, 2000; Zellman \& Waterman, 1998). This style includes setting high expectations, providing emotional support, granting appropriate autonomy, acknowledging a child's perspective, setting limits, explaining the parent's position, and encouraging discussions. During a teacher's conversation with parents these types of behaviors, especially frequent discussions about school, should be emphasized. 


\section{THE NEED FOR TEACHER TRAINING}

While the literature informs, and the government mandates, it is the classroom teacher who plays the critical role in fostering alliances with parents (Jacobsen, 2002). But before this can happen our teacher education programs must provide preservice teachers with the necessary training. This training should help candidates reflect upon their own concerns and assumptions about parental involvement, involve in-depth study of the issues surrounding parent home alliances, and provide candidates with opportunities to develop a variety of skills and strategies essential for success. These goals can be best accomplished by developing programs that integrate training during both seminars and field experiences.

to:

During the seminars candidates should be introduced to the issues of parental involvement and be required

1. respond to a survey measuring their own beliefs and concerns regarding parental involvement, as well as their perceived skills to involve parents.

2. explain the importance of the parents' role in their children's education and the resulting benefits.

3. describe the importance of the teacher's role in involving parents and the resulting benefits.

4. describe the parental behaviors most critical to academic success.

5. cite the obstacles that both parents and teachers must overcome in fostering alliances.

6. develop samples of written communication to the home such as welcoming letters, progress reports, and certificates of achievement.

7. role-play effective conferencing skills such as active listening, open ended questions, and empathic responding.

8. invite parents to the seminar or interview parents for the purpose of understanding parents' perspectives.

9. complete an exit survey to measure any changes in preservice teachers' beliefs and concerns.

During the candidates' field experiences they should continue developing communication skills by:

1. writing welcoming letters to all parents informing them that they will be working with their child for a specified period of time.

2. sitting in on parent-teacher conferences.

3. calling parents to notify them of student progress.

4. participating in Back-to-School events, PTA meetings, and other parent-related activities.

\section{CONCLUSION}

The importance of parental involvement in a child's academic success is inarguable. The literature has clearly identified the benefits of parent participation, discussed the most critical parental behaviors, and delineated the obstacles facing parent - home collaboration. Unfortunately, after decades of research and discussion, too many parents are still disengaged from school. The classroom teacher is the key to changing the level of parental participation. But this will only occur when our teacher education programs start to implement the recommendations found in the literature and finally provide preservice teachers with the skills and strategies necessary for fostering alliances with those who are so critical to a child's success in school, the parents.

\section{REFERENCES}

1. Aronson, J. Z. (1996). How schools can recruit hard-to-reach parents. Educational Leadership, 53(7), 58-60.

2. Ascher, C. (1988). Improving the school-home connection for poor and minority urban students. Urban Review 20, 109-123.

3. $\quad$ Bandura, A. (1997). Self-efficacy: The exercise of control. New York: W. H. Freeman.

4. Ballantine, J. (1999, Spring). Getting involved in our children's education. Childhood Education, 75(3), 170171. 
5. $\quad$ Becher, R. (1984). Parental improvement: A review of research and principles of successful practice. Washington, DC: National Institute of Education.

6. Becker, H. J. \& Epstein, J. L. (1982). Parent involvement: A survey of teacher practices. Elementary School Journal, 83, 85-102.

7. Broderick, P. C. \& Mastrilli, T. (1997). Attitudes concerning parent involvement: Parent and Teacher perspectives. Pennsylvania Educational Leadership, 16, 30-36.

8. Brown, D. (1999). Improving academic achievement: What school counselors can do. ERIC Document Reproduction Service No. 435895.

9. Burns, B. (2000). How to manage parent-educator relations in an affluent community. Journal of Educational Relations, 21(20), 29-37.

10. Chen, X. \& Chandler, K. (2001). Efforts by public K-8 schools to involve parents in children's education: Do school and parent reports agree? National Center for Education Statistics (Report No. 2001-076). Washington, DC: Department of Education.

11. Christensen, S. L. \& Cleary, M. (1990). Consultation and parent-education partnership: A perspective. Journal of Educational and Psychological Consultation, 1, 219-241.

12. Clark, R. M. (1983). Family life and school achievement: Why poor black children succeed or fail. Chicago: University of Chicago Press.

13. Cochran, M. (1987). The parental empowerment process: Building on family strengths. Equity and Choice, 4, 9-24.

14. Coleman, M. (1991). Planning for parent participation in schools for young children. ERIC Document Reproduction Service No. 342463.

15. Columbo, G. (1995). Parental involvement: A key to successful schools. NASSP Bulletin, 79(567), 71-75.

16. Darling, N. \& Steinberg, L. (1993). Parenting style as context: An integrative model. Psychological Bulletin, 113(3), 487-496.

17. de Acosta, M. (1996). A foundational approach to preparing teachers for family and community involvement in children's education. Journal of Teacher Education, 47, 9-15.

18. Dornbusch, S. M. \& Ritter, P. L. (1988). Parents of high school students: A neglected resource. Educational Horizons, 66, 75-77.

19. Dweck, C. S. (1986). Motivational processes affecting learning. American Psychologist, 41, $1040-1048$.

20. Epstein, J. L. (1984). Effects on parents of teacher practices in parental involvement. Baltimore: Johns Hopkins University, Center for Social Organization of Schools.

21. Epstein, J. L. (1995). School/family/community partnerships: Caring for children we share. Phi Delta Kappan, 76(9), 701-712.

22. Fero, G. \& Bush, B. (1994). Beginning teacher perceptions of parent's role in an educational setting. Paper presented at the annual meeting of the Association of Teacher Educators, Chicago, IL.

23. Finn, J. D. (1998). Parental engagement that makes a difference. Educational Leadership, 55(8), 20-24.

24. Fowler, J. W. \& Peterson, P.L. (1981). Increasing reading persistence and altering attributional style of learned helpless children. Journal of Educational Psychology, 73, 251-260.

25. Gonzalez, A., (2002). Parental involvement: Its contribution to high school students' motivation. Clearing House, 75(3), 132-134.

26. Greenwood, G. \& Hickman, C. (1991). Research and practice in parent involvement: Implications for teacher education. The Elementary School Journal, 91(3), 279-288.

27. Hara, S. R. \& Burke, D. J. (1998). Parent involvement: The key to improved student achievement. The School Community Journal, 8, (2), 9-18.

28. Haynes, N., Comer, J., \& Hamilton-Lee, M. (1989). School climate enhancement through parental involvement. Journal of School Psychology, 27, 87-90.

29. Henderson, A. T. (1987). The evidence continues to grow: Parent involvement improves students. Columbia, MD: National Committee for Citizens Education.

30. Henderson, A. T., Marburger, C. L., \& Ooms, T. (1986). Beyond the bake sale: An educator's guide to working with parents. Columbia, MD: National Committee for Citizens in Education.

31. Hickman, C. W., Greenwood, G., \& Miller, M. D. (1995). High school parent involvement: Relationships with achievement, grade level, SES, and gender. Journal of Research and Development in Education, 28(3), 125-135. 
32. Hinz, L., Clarke, J., \& Nathan, J. (1992). A survey of parent involvement course offerings in Minnesota's undergraduate teacher preparation programs. Minneapolis, MN: University of Minnesota, Center for School Change, Hubert H. Humphrey Institute of Public Affairs.

33. Hoover-Dempsey, K. V., Bassler, O. C., \& Brissie, J. S. (1987). Parent involvement: Contributions of teacher efficacy, school socioeconomic status, and other school characteristics. American Educational Research Journal, 24, 417-435.

34. Hoover-Dempsey, K. V., Bassler, O. C., \& Brissie, J. S. (1992). Explorations in parent-school relations. Journal of Educational Research, 85, 287-294.

35. Hoover-Dempsey, K. V., \& Sandler, H. M. (1997). Why do parents become involved in their children's education? Review of Educational Research, 67(1), 3-42.

36. Hoover-Dempsey, K. V., Walker, J., Jones, K. P., \& Reed, R. P. (2002). Teachers involving parents (TIP): Results of an in-service teacher education program for enhancing parental involvement. Teaching and Teacher Education, 18, 843-867.

37. Huss-Keeler, R. L., (1997). Teacher perception of ethnic and linguistic minority parental involvement and its relationships to children's language and literacy learning: A case study. Teaching and Teacher Education, $13,171-172$.

38. Hughes, C. A. (2003). What teacher education programs can learn from successful Mexican-descent students. Bilingual Research Journal, 27(2), 225-244.

39. Inger, M. (1992). Increasing the school involvement of Hispanic parents. (Report No. EDO-UD-92-3). Washington, DC: Office of Educational Research and Improvement. (ERIC Document Reproduction Service No. ED350380.

40. Jacobson, L. (2002). Summit connects parents and teacher ed. Education Week, 22(12), 3.

41. Johnson, G. M. (1998). Principles of instruction for at-risk learners. Preventing School Failure, 42(4), 167174.

42. Johnson, L. R. \& Webster, E. G. (1994). Develop a public relations plan for special education. Journal of Educational Relations, 25(3), 33-37.

43. Katz, L. G. (1996). Preventing and resolving parent-teacher differences. ERIC Document Reproduction Service No. 401048.

44. Kurdek, L., Fine, M., \& Sinclair, R. (1995, April). School adjustment in sixth graders: Parenting transitions, family climate, and peer norm effects. Child Development, 66(2), 430-445.

45. Langdon, C. \& Vesper, N. (2000). The sixth Phi Delta Kappa poll of teachers' attitudes toward the public schools. Phi Delta Kappan, 81(8), 607-611.

46. Lazar, A., Broderick, P., Mastrilli, T., \& Slostad, F. (1999, Spring). Educating teachers for parent involvement. Contemporary Education, 70(3), 5-10.

47. Lazar, A. \& Slostad, F. (1999). How to overcome obstacles to parent-teacher partnerships. Clearing House, 72(4), 206-211.

48. Long, J. D., \& Williams, R. L. (2005). Making it till Friday (5 ${ }^{\text {th }}$ ed.). Hightstown, NJ: Princeton Book Company.

49. Loucks, H. (1992). Increasing parent / family involvement: Ten ideas that work. NASSP Bulletin, 76(543), 19-23.

50. Masten, A. S. \& Coatsworth, J. D. (1998). The development of competence in favorable and unfavorable environments: Lessons from research on successful children. American Psychologist, 53, 205-220.

51. Morris, V. G., Taylor, S. I., Knight, J., \& Wasson, R. (1995, January). Preparing preservice teachers to take leadership roles in parent involvement programs in schools. Paper presented at the annual meeting of the Association of Teacher Educators, Detroit, MI.

52. Muller, C. (1993). Parent involvement and academic achievement: An analysis of family resources available to the child. In B. Schneider \& J. S. Coleman (Eds.), Parents, their children, and schools (pp. 77-114). Boulder, CO: Westview.

53. National Council for Accreditation of Teachers. (1994). NCATE standards. Washington, DC: Author.

54. National PTA. (1997). National standards for parent/family involvement programs. Chicago: Author.

55. Norton, M. S. \& Nufeld, J. C. (2002, Winter). Parental involvement in schools: Why it is important and how to get it. Journal of School Public Relations, 23, 45-57. 
56. Robertson, A. S. (1997). If an adolescent begins to fail in school, what can parents and teachers do? ERIC Document Reproduction Service No. 415001.

57. Reed-Danahay, D. (1996). Education and identity in rural France: The politics of schooling. Cambridge, England: Cambridge University Press.

58. Rosenzweig, C. J. (2000). A meta-analysis of parenting and school success: The role of parents in promoting students' academic performance. Dissertation Abstracts International, 61(04), 368A. (UMI No. 9968470)

59. Rich, D. (1988). Bridging the parent gap in education reform. Educational Horizons, 66, 90-92.

60. Schweiker-Marra, K. E. (2000, Summer). Changing teacher attitudes and actions to promote better parentteacher communications. ERS Spectrum, 12-18.

61. Solo, L. (1997). School success begins at home. Principal, 77(2), 29-30.

62. Steinberg, L. (1996). Beyond the classroom: Why school reform has failed and what parents need to do. New York: Simon \& Schuster.

63. Stevenson, H. (1983). Making the grade: School achievement in Japan, Taiwan, and the United States. Paper presented at the Center for Advanced Study in the Behavioral Science, Board of Trustees, Stanford, CA.

64. Tichenor, M. S. (1997, December). Teacher education and parent involvement: Reflections from preservice teachers. Journal of Instructional Psychology, 24(4), 233-339.

65. Tizard, J., Schofield, W., \& Hewison, J. (1982, February). Collaboration between teachers and parents in assisting children's reading. British Journal of Educational Psychology, 52, 1-15.

66. U.S Department of Education. (1994). Strong families, strong schools: Building community partnerships for learning. Washington, DC: Author.

67. U.S. Department of Education. (1996). Youth indicators 1996/children of single parents. (NCES Publication). Washington, DC: Author

68. U.S. Department of Education. (1998). Factors associated with fathers' and mothers' involvement in their children's schools. (National Center for Education Statistics No. 98-122. Washington, DC: U.S. Author

69. Vincent, C. (1996). Parents and teachers: Power and participation. London: Falmer Press.

70. Zellman, G. L. \& Waterman, J. M. (1998). Understanding the impact of parent school involvement on children's educational outcomes. Journal of Educational Research, 91(6), 370-380. 